\title{
Sexuality, Textuality: The Cultural Work of Plagiarism
}

\section{Rebecca Moore Howard}

I never saw a purple cow;

I never bope to see one.

But I can tell you anybow

I'd rather see than be one.

-Gelett F. Burgess

A

few years ago, The Council Chronicle, a periodical that comes shrink-wrapped with subscription issues of College English, asked readers, "We Want to Know: How Do You Define Plagiarism?” A provocative question, it would seemone that would certainly interest teachers of English, people who "have to deal with" plagiarism from time to time. Two subsequent issues published a variety of definitions of plagiarism (see "Plagiarism in the Classroom" and "What Do You Do"). No consensus was reached, but readers were undoubtedly interested and stimulated by the conversation.

All over the country, meanwhile, students were and still are being upbraided, reprimanded, given F's on papers, flunked in courses, and expelled from universities for doing this plagiarism thing, this indefinable thing.

The jarring disjunction of these combined scenarios-teachers unable to define a term on the basis of which they are punishing students-suggests that something far more complex than a not yet defined term is at stake. If the term were definable, surely that work would by now have been accomplished. But if the term is inherently indefinable, how is it that the academy still manages to use it as the basis for serious legislation and adjudication?

Rebecca Moore Howard (kati9e9@citlink.net) is Associate Professor of Writing and Rhetoric at Syracuse University. Her scholarship in stylistics and print culture endeavors to negotiate amongst textbased pedagogy, lay and academic assumptions about literacy, and contemporary theory.

College English, Volume 62, Number 4, March 2000 
Plagiarism eludes definition because it does far more work than it admits to. The term admits to doing textual work, labeling texts that include significant unacknowledged borrowings from other texts. When teachers make judgments about whether a student has plagiarized, those judgments are supposedly made solely by examining the plagiaristic text and the sources it appropriates. College regulations against plagiarism typically exclude the author and his or her intentions from the adjudication of cases. But if this textual fantasy were true-if, indeed, plagiarism could be identified only in texts - then it would be readily subject to definition. One could define plagiarism (as some now-excoriated academic myths do) according to quantitative formulae that calculate the number of words appropriated. ${ }^{1}$

But the discourse of plagiarism regulates not only textuality but sexuality. Embedded in the discursive construction of plagiarism are metaphors of gender, weakness, collaboration, disease, adultery, rape, and property that communicate a fear of violating sexual as well as textual boundaries. To regulate textual relationsand specifically the generalized field of plagiarism - is to regulate the gendered, sexualized body. Hence plagiarism continues to elude definition, for teachers cannot possibly formulate and act on a definition of plagiarism that articulates both its textual and sexual work.

Consider a second pair of scenarios: Contemporary theory rejects the possibility of original, uninfluenced writing and even the possibility of fully acknowledging one's sources. 2 "Even our most sublimely 'original' moments," says Kurt Spellmeyer, "cannot escape the grid of constructed meanings and uses ..." (84). Françoise Meltzer limns the consequences of striving for originality: "The anxiety of being influenced (the oedipal problem and so on) is but one symptom within the larger systemic disorder that I have called a metaphysics of origin" (159). Not only is originality a chimera, but so is citing one's sources; Susan Stewart explains, "An ideal . . . device of citation would be a full (and necessarily impossible) history of the writer's subjectivity ..." (25). Elizabeth Rankin would seem to concur: "And besides, the simple truth is that I couldn't begin to name all the sources of my own theoretical thinking" (84).

Yet English teachers-and college plagiarism policies-continue to require originality in student writing. The current edition of the Harbrace College Handbook legislates, "The foundation of researched writing is always the writer's own ideas, which flow from point to point, supported and guided by research" (Hodges et al. 476). And the Cornell University "Code of Academic Integrity" asserts the possibility of full citation: "If materials are taken from published sources the student must clearly and completely cite the source of such materials" (2). Neither the Harbrace nor the Cornell policy is unusual; these are the standard representations of textuality in college writers' handbooks and universities' academic regulations.

We in the academy and specifically in English Studies believe that the textual work required by the discourse of plagiarism is impossible, yet we continue to require that work of our students. We do this despite a growing scholarship that challenges 
these practices, a scholarship that in 1999 included the publication of the first two books that theorize the discursive construction of student plagiarism (see Howard, Standing, and Buranen and Roy).

Through much of my academic career I have striven to understand and remedy these conundrums. At first the received categories and definitions of plagiarism made sense to me, but the further I pushed, the more unsatisfactory I found them. In 1986 I began crafting pedagogy that I hoped would teach my students how to avoid plagiarism. That classroom work led to scholarly work: My earliest publication on the topic asserted that patchwriting, a textual activity commonly classified as plagiarism, might be of positive value as a composing strategy (Howard, "Plagiarism Pentimento"). A subsequent article argued that patchwriting should be adjudicated differently than other forms of plagiarism (Howard, "Plagiarisms, Authorships"). Then I wrote a book that went a step further, advocating that patchwriting be removed entirely from the juridical category of plagiarism (Howard, Standing).

And now I take the additional step of proposing that we in English Studies discard the term plagiarism altogether. Some of my reasons for this proposal are embedded in my previous work: The comprehensive term plagiarism asserts a unity among disparate textual practices (Howard, Standing 157-59); it often differentiates intentional and unintentional violations but derives these judgments from features of text, not from actual authors' intentions (107-10); it asserts a moral basis for textual phenomena that are a function of reading comprehension and community membership, not ethics (Howard, "Ethics"); and it supports the worst sort of liberal-culture gatekeeping, maintaining false distinctions between high and low literacy (Howard, "New Abolitionism" 88). Now my recognition of the unacknowledged work of plagiarism - its regulation of student bodies - pushes me to the further step of rejecting the very word.

I take this step because the metaphors for plagiarism raise two insuperable problems for English teachers: First, they draw the teacher into an amorphous cultural regulation of the body, a regulation that wholly exceeds the scope most of us would claim for our work. Second, this cultural regulation in which the discourse of plagiarism involves us is hierarchical in the very ways that many of us abhor. To adjudicate plagiarism in these circumstances is to work against the liberatory, democratic, civic, and critical pedagogies that prevail in English Studies. My remedy for the problem of plagiarism's metaphors is therefore to use more specific, less culturally burdened terms: fraud, insufficient citation, and excessive repetition. A review of the culprit metaphors will demonstrate the urgency of this recommendation.

\section{Gendering Authorship}

Women are (to adapt Irigaray's phrase) "this author which is not one." In the metaphors through which plagiarism is commonly represented, feminist scholars have discovered women to be not authors but the threat to authorship. Given the age-old 
male/female binary, in which the masculine is strong and admirable, the feminine weak and contemptible ("You throw like a girl"), the association of women with plagiarism reinforces plagiarism as the most loathsome form of authorship. In an illustrative description of academic writing, William Perry's explanation of exam-taking employs a bovine metaphor that genders writing. Perry observes that students who write only "bull" (generalizations) on their exams should receive higher grades than those who adduce only "cow" (specifics). Whereas the cow (female) shows only rote, obedient learning, the bull (male) indicates subtlety and a grasp of the abstract. The "bullster" is a "colleague" whom one can "trust" - a student who "at least understands the problems of one's field" and who can, when motivated to do so, readily acquire the necessary concrete (feminine) data (255-57). Here Perry draws on the familiar attribution of abstraction (the intellect) to masculinity and concreteness (the body) to femininity. Perry reinforces this hierarchy in his "wedding" of the two:

I can now at last let bull and cow get together. The reader knows best how a productive wedding is arranged in his own field. This is the nuptial he celebrates with a straight A on examinations. The masculine context must embrace the feminine particular, though itself "born of woman." Such a union is knowledge itself, and it alone can generate new contexts and new data which can unite in their turn to form new knowledge. $(258-59)$

The cultural work of Perry's metaphors for academic writing requires little translation: Masculinity is intellectually subtle, femininity is not.

In other accounts, the bovine metaphor for authorship is even simpler. Charles Reade's nineteenth-century use of the metaphor has all writers working from sources - and these sources are the bodies of female animals from which the writer extracts concrete products that become text: "All fiction, worth a button, is founded on facts. . . I rarely write a novel without milking about two hundred heterogeneous cows into my pail" (qtd. in Mallon 46). Novelist and critic Thomas Mallon lends contemporary affirmation to the metaphor when he slyly remarks, "Most novelists perform the same chore less loudly on a smaller herd" (46).

A far more nuanced gendering of authorship informs the criticism of Harold Bloom (whose account of authorship is partially explicated in Sandra M. Gilbert and Susan Gubar's oft-anthologized analysis). Bloom has an abiding interest in "strong" poets, and his description employs metaphors of the body. He depicts the writer's precursors as poetic fathers who mate with muses, but the mating, says Bloom, does not produce the poet-child. Instead, the poet-child has to produce himself, has to father himself by breaking free of the influence of the poetic father (37). Integral to creativity is the poet's mating with his muse, but that mating is fraught with the anxiety of sexual territoriality: "His word is not his own word only, and his Muse has whored with many before him" (61). In Bloom's account, the authorial function of the feminine is to inspire the originary male, but the female, far from trustworthy, is a trollop. She is an essential part of the male's creativity, but finally the male must go it alone. 
Gilbert and Gubar detail some of the consequences of Bloom's argument: In a culture of compulsory heterosexuality, women may not mate with other women, with the female muse; hence they cannot be original. Nor, in the ordinary course of things, can they be fathers. Patriarchy reduces women to the stereotypes of angel and monster. Hence the woman writer's precursors are part of the patriarchal authority that she must overcome in order to be creative (Gilbert and Gubar 291-92).

But one word in Bloom's book-one adjective-serves as a key piece of the puzzle in which the cultural construction of authorship and plagiarism draws on and contributes to the cultural construction of binary gender. It is "strong" poets who can father themselves, "strong" poets whom Harold Bloom values. "Strong" writing is, in Anglo-American culture, a masculine virtue. Miriam Brody notes that Quintilian was the major source for the Enlightenment's concept of "good writing as the embodiment of masculine virtues" and "effeminacy as the representation of weak writing," a representation that was realized in Quintilian's figure of the eunuch. Working from Quintilian, eighteenth-century rhetoricians—and twentieth-century authors such as Robinson Shipherd—defined good writing as "manly, noble, and chaste." Plagiarism, a notion whose cultural work has increased in importance since the late nineteenth century, enabled a differentiation of the merely literate (the feminine) from "strong," masculine writers: "The responsibility to pursue manly eloquence was elevated to the binary struggle to maintain the structure of gender as it had been cast" (Brody 30).

The gendering of authorship, then, involves the equation of masculinity, abstraction, strength, and originality. It also involves a less straightforward equation of women, specificity, and plagiarism. Investigating the association of women with plagiarism, Brody describes Shipherd's 1926 work (The Fine Art of Writing for Those Who Teach It), which she identifies as the first composition book to offer an extended, gendered warning against plagiarism:

Just as Shipherd's notion of plagiarism benefited from images of dangerous promiscuity, so too gendered representations of failures in writing emerged in his description of good style.... Faithful to the imagery in [Quintilian's] Institutes, whose wisdom Shipherd passed on without identifying the source, Shipherd offered a phallic representation of good writing, after paraphrasing Quintilian's remark that we must speak so that we are not misunderstood. [Shipherd's] most morally impaired plagiarist, who might contaminate the social body if not segregated from it, "couldn't write a sentence that would stand erect"; hence when he borrowed someone else's prose, his theft was self-evident. (174-75)

In his phallic metaphors, Shipherd is specific in linking originality to the masculine, plagiarism to the feminine.

To buy into the rhetoric of authorship that pits masculine autonomous authorship against feminine plagiarism is to reject collaboration — a method of writing commonly associated with or especially valued by women. ${ }^{3}$ Collaboration involves one writer being influenced by another, whereas in the male-dominated authorship of the modern West, authors are supposed to be autonomous. If they must collaborate, they 
must do so hierarchically, not dialogically — thus preserving their autonomy and individuality (see Lunsford and Ede 133). Yet both Bloom and Mallon, whose works extol the autonomous, strong, male writer, acknowledge that all writing is influenced; none is autonomous. Oscar Wilde and Wallace Stevens, says Bloom, suffered the anxiety of influence, the desire to be free of precursors, "the melancholy of the creative mind's desperate insistence upon priority" (13). Their suffering, he maintains, was needless. They did not recognize that intrapoetic relationships are inevitablethat ending poetic influence would be the death of poetry. Mallon would seem to concur: "Our imaginations are only the jumble of what we see and hear; creativity lies more in the mixing than the making" (126).

Though they both appear to assert that no writing is original, neither Harold Bloom nor Thomas Mallon is happy with that assertion, for neither likes textual collaboration. The communalism that is collaboration is insufficient for Mallon; instead, he postulates individuation as the desired outcome of the creative process. He believes that the originary artist begins work in the shadow of others and then moves from community to individuality (123). Despite his declaration that all poets are influenced, Bloom too subscribes to the ideal of originality. All poets, he says, are influenced by precursors, but their creativity comes through their misinterpretation of these sources - their misprision. The poet (or critic) takes a Lucretian swerve away from the source(s) that influenced him and thus creates new meaning (78-79). Bloom admits his own attachment to "a Romantic and prophetic humanism" that imagines the earliest poets as shamans who created "ceremonial magic" that was "founded upon divination," with "primordial chaos" as the fountainhead of poetic creativity. But in contemporary guilt culture, he says, the poet cannot return to fresh chaos and thus cannot tap into poetic wisdom (59-61). He must perforce succumb to influence (i.e., to weak, feminine, textual collaboration) while producing good (i.e., strong, masculine, solitary) poetry in the struggle against it.

This might suggest the possibility that women can be writers, albeit devalued writers who represent the negative opposite of masculine, autonomous originality. But in the mutually entailed metaphors regulating textual relations, women are allowed no agency in writing, not even as plagiarists. Their role is entirely that of object. Part of that object role is to inspire the masculine writer. Shipherd, for example, depicts feminine writing as the negative opposite of good (manly) writing but suggests that a woman's influence on men is salutary because it tempers men's will to power by "requir[ing] the chivalric attention of her male protector" (Brody 168-69). But even for the humble role of woman as inspiring object, Françoise Meltzer offers contradictory evidence: Freud's Civilization and Its Discontents describes women as an obstruction to creativity (Meltzer 32-33). In Meltzer's reading of Freud, the feminine threatens men's writing. Men must acknowledge the feminine as the "passive and unproductive" elements in their work, or they will themselves become feminized: 
The plagiarized text itself is a feminized object, that which is kidnapped and, Helenlike, forced into another's camp. The feminine and its connection to knowledge are already deeply implicated in both of the philosophies considered here: Descartes likens science to a woman, just as Freud endows the unconscious with feminine attributes. Both science and a woman are "mysterious" and need to be "conquered" (Descartes); both woman and the unconscious are enigmas which must be "solved" and, like the dark continent to which they are compared, charted (Freud). (Meltzer 41)

These gendered metaphors of authorship and its transgressive variant, plagiarism, advance arguments- the implicit, unstated, enthymematic arguments whose burden cultural metaphors bear. And they participate in a highly articulated, very explicit modern economy of authorship in which only the writer who can work alone, autonomously, free of others' influence, can produce an "original" text. ${ }^{4}$ And that author of original text is male.

\section{Linking Sexual Property \\ to Textual Transgression}

In this textual economy, when the writer does produce original text he is accorded ownership of it. Along with gendered authorship, the notion of literary property contributes to a mutual constitution of authorship, gender, and sexual preference. Meltzer's reference to the plagiarized text as a feminized, kidnapped object draws on a metaphor as ancient as the word plagiarism. Though the word first appears in English only in the seventeenth century, it is derived from the Latin term for kidnapping, a term whose meaning the Roman poet Martial extended to include not only the stealing of slaves but also textual appropriation. The association of plagiarism and kidnapping thus has a long history in Western culture, and woman as object participates in both.

So does paternity as metaphor. The writings of Daniel Defoe and Joseph Addison asserting the rights of authors are inscribed with metaphors of paternity and the author as tiller. But Mark Rose points out that Defoe runs afoul of his own metaphor when he plays on the origin of the word plagiary, with its implications of kidnapping. If plagiarists are child-stealers, as Defoe says they are, then authors are those who sell their own children (Rose 39).

Defoe receives the paternity trope from the courtly culture of the Renaissance, but his usage evokes a distinctly middle-class patriarchal domesticity. Indeed, Defoe characteristically associates literary property with family, house, and home, as in the Essay on the Regulation of the Press when he speaks of the invasion of authors' properties as "every jot as unjust as lying with their Wives, and breaking-up their Houses." (Rose 40)

Writing in 1976, A. E. Malloch provides modern validation for the paternity trope when he specifies the importance of the metaphor of kidnapping to describe plagiarism: " []$] \mathrm{f}$ there's any crime involved, it's kidnaping rather than theft. That's what 
the word comes from, you know. Plagiare. Late Latin, to kidnap. Not to steal something, but someone. If you plagiarize, you take unlawful possession of another person, and compel her to pretend to be you" (Malloch 165). Malloch chooses the feminine pronoun ber to refer to that which is unlawfully possessed and plagiarized. The feminine-or, more accurately, the feminized-plagiarized text. That which is kidnapped or plagiarized is feminized. Regardless of its gender prior to its appropriation, by its appropriation it becomes feminized.

The argument-by-metaphor that associates authorship with a proprietary, chaste, heterosexual, rational masculinity is further advanced in the description of plagiarism as disease, either mental or sexual disease. Describing the plagiarist as a person of excuses, Thomas Mallon offers an elaborate explanation. The standard excuses for plagiarism, he says, are "sloppy note-taking and hasty composition" (36). But he differentiates excuses and causes. The excuses of sloppy note-taking and hasty composition are one part of the cause of plagiarism, but plagiarists do not willingly admit the other part: bad motives (183). Reviewing E. B. White's three categories of plagiarists - thieves, dopes, and the "total recall guys"-Mallon dismisses the total recall plagiarist as implausible and gives his own account of the "dope": "that sort of plagiarist ... 'who is a little vague about the printed word and regards anything in the way of printed matter as mildly miraculous and common property" "(192). Having rejected one of White's three categories of plagiarists, the total recaller, Mallon offers his own substitute: the "pathological," the compulsive plagiarist (192). Nor is he alone in attributing psychological imbalance to the plagiarist; Marilyn Randall mentions several theorists who hold similar beliefs, including Michel Schneider, who diagnoses Freud and other members of the Vienna Circle as victims of the neurosis of plagiarism (Randall 540, n. 20).

Shipherd's 1926 guide for composition teachers makes the association of plagiarism with sexual disease abundantly clear. Brody explains that Shipherd describes the teaching of composition as the development of character (166), warning against students' plagiarism, which he associates with venereal disease. Representing plagiarism as a moral and legal offense, Shipherd compares it to a sexually transmitted disease, calling it the "moral problem of our subject," our "bete noir of sex hygiene." Brody continues, "Although Shipherd recognized the occasional irremediable reprobate, someone 'dangerously immoral' who should be 'segregated' from 'the social body,' he located theft of ideas as a pestilence students may be taught to avoid contracting, as they are taught to claim possession of their uniquely individual thoughts" (174).

Disease is, of course, of the body, and a prominent tradition in the West says that the body is the feminine. ${ }^{5}$ Peter Stallybrass and Allon White note that the expression "the Great Unwashed" emerged in the 1830s in England. At that time, fear of contamination ran rife, resulting in a fear of touching. " Contagion' and 'contamination,', they say, "became the tropes through which city life was apprehended," and the fear of contamination extended beyond hygiene to a fear of the "spiritually inferior" (135-36). 
In the modern economy of authorship, the spiritually inferior is, of course, the plagiarist, the binary opposite of the true and thus moral author, the masculine. The immorality of plagiarism is infectious, capable of contaminating (feminizing) those who come into contact with the offender. Mallon describes one writer's compulsive plagiarism as a "virus" (81). The Chronicle of Higher Education reviews the "recent rash of plagiarism cases" (Mooney A13). As a result of surveying students in introductory courses at Miami University of Ohio, Jerold Hale (or the newspaper reporter interviewing him) concludes that plagiarism is "an epidemic" ("Plagiarism Is Rampant"). And Margaret S. Geosits and William R. Kirk, as well as Terry Nienhuis, offer a "cure." Augustus Kolich adds the companion image of rot and decay: "The worm plagiarism spoils the fruit of intellectual inquiry and reason, and starves the seeds of originality that foster such inquiry" (145).

Plagiarism is a disease; disease is of the body (the spiritually inferior body or the deranged mind excessively influenced by the body); and the body, Aristotle and his successors have convinced us, is the feminine. The disease of plagiarism often takes the form of mental illness, and that too is gendered. Gilbert and Gubar offer an extensive treatment of the "madness" of authorship as a female madness. Women writers of centuries past often depicted themselves—or were depicted by others-as mad. My favorite example comes from John Winthrop: "In 1645 John Winthrop, the governor of the Massachusetts Bay Colony, noted in his journal that Anne Hopkins 'has fallen into a sad infirmity, the loss of her understanding and reason, which had been growing upon her divers years, by occasion of her giving herself wholly to reading and writing" (Gilbert and Gubar 296). The female writer is mad, Winthrop tells us with breathtaking candor. And so is the plagiarist, Mallon explains. The absence of originality that is plagiarism is associated with the feminine; hence plagiarism, through its association with the female author who is mad, is a female madness.

The argument advanced by the metaphors for plagiarism becomes even more repugnant when one considers the familiar association of plagiarism with adultery. When Defoe speaks of the invasion of authors' properties as "every jot as unjust as lying with their Wives, and breaking-up their Houses" (qtd. in Rose 40), the image seems a logical extension of the association between the stealing of slaves and the appropriation of texts. Robinson Shipherd portrays the teaching of composition as the development of character and compares plagiarism to sexual promiscuity. And when critic Theodore Pappas and historian David Levering Lewis denounce the plagiarism of Martin Luther King Jr., they conjoin it with his adultery. Attacking Keith D. Miller's account of King's textual strategies as “voice merging," Pappas declares,

Miller's defense of King and his novel approach to plagiarism are both predictable. Polygamy, female circumcision, animal sacrifices, and witchcraft have all become acceptable so long as they are practices of preferred minorities, and if Mr. King 
seduced underage girls, then statutory rape must be redefined as mere erotic exuberance or as an assault on children's rights. (41)

Reconsidering his biography of King in light of new evidence about the man, Lewis segues back and forth between the "sexual potholes in Dr. King's career" (81) and his "fraudulent" academic career. He calls the voice-merging argument "curious" and concludes, "A picture emerges of King the young graduate student tooling about Boston on dates in his green Chevrolet, cavalierly submitting essays and dissertation chapters that were mosaics of the works of others ..." (85). A little more suave than Robinson Shipherd, neither Pappas nor Lewis argues directly for a hypotactic, causal relationship between King's sexual and textual activities. But the possibilities and implications of Pappas's and Lewis's paratactic arguments are unmistakable, even unavoidable. Plagiarism and sexual transgression are two sides of one coin.

Similarly, James Campbell, reviewing the book in which Neal Bowers describes the experience of being plagiarized, does not squander the opportunity to point out that Bowers's plagiarist, David Jones, also had a history of sexual assault. The connection, in Campbell's language, is one of chronology but also causality: "Eventually, it was discovered that Jones's career as a molester of poems followed on from a history of sexually assaulting young girls at schools where he had been a teacher" (n.p.; emphasis added).

Adultery can be committed by male or female, though all of the allusions here cited are specific to the male. The default category for rape, however, is genderspecific: The male commits rape upon the female. This metaphorical commonplace serves as a keystone to understanding the cultural work of plagiarism. The claim that plagiarism is a form of rape has quite a tradition in Western culture. Wendy Wall describes the writing of Thomas Dekker, one of many Renaissance writers who deny a desire to publish. Anthony Scoloker, she says, parodies such authors' disavowals when he refers to publishing as undergoing "a Pressing"-a double entendre suggesting "loss of authorial virginity" (1). Wall explains that when Scoloker equates publishing with forced entry, he is drawing on the "conventional gesture" of using "the axis of gender to encode anxieties about unauthorized social and textual circulation in early modern England" (3). In this encoding of anxieties, women were tropes: "Gender . . provides a focal point . . . for querying the issues of authorship, privacy, and class energized by the spread of print technology" (Wall 7). Pappas introduces the word rape into his description of the plagiarism of Martin Luther King Jr. (41). And Thomas Mallon has frequent recourse to images of plagiarism as rape $(105,134$, 164), imagining plagiarizing professors as potential corrupters of their students (172, 177). The images of rape wielded by Scoloker, Pappas, Mallon, and many other commentators on authorship in the modern period make it impossible to feel that one has reached closure by observing that originality is strong and masculine while plagia- 
rism is variously weak, feminine, adulterous, or diseased. If plagiarism is rape, we must examine the usual associations with the act of rape: It is committed by a malea strong male-upon a weak, normatively female body. Plagiarism as rape therefore evokes images of strong violence.

The key question is who is being raped. Is it the originary, proprietary, male author? Or is it his property, his text? Since the plagiarist has recourse not to the person of the proprietary author but to his text, it is the text that plays the feminine role of rape victim. The outrage of plagiarism, therefore, is that the text belongs to the proprietary-male-author. That proprietary author is male: In the Western tradition, women do not own the product of their labor and thus cannot, in the Lockean sense, be authors. Nor, in the terms of traditional heterosexuality, can they be rapists and hence not plagiarists. All this prepares the ground for excluding them entirely from the category of "writer."

Women, as Harold Bloom's image of the poet-father establishes, are not original, cannot influence those who are, and cannot be relied on to be faithful to those who are. The metaphor of disease demonstrates that the loathsome, infectious literary practice that is plagiarism serves as trope for the female. The metaphor of kidnapping brings out the association of criminality, the forbidden. The metaphor of adultery does the same, but also evokes anxieties of sexual territoriality, assigning the female (for whom the plagiarized text stands) to the role of property. The rape metaphor for plagiarism further establishes that women are not subjects, capable of the volition that is plagiarism. They are instead objects, property, subject to violation.

Both poles of the authorship binary-the privileged pole of the author and the negative pole of the plagiarist-are thus occupied by the male. At the privileged pole, it is only the male who is capable of originality; at the negative pole, only the male is capable of rape. Thus the regulation of textual relations mirrors and participates in the regulation of sexual relations. To plagiarize is to violate the sexual territory and property of another: Plagiarism amounts to one man's raping another man's female property. The occupation of both poles effectively eliminates women from any consideration as authors.

One step remains for a full understanding of the mutual constitution of authorship, gender, and sexuality: When we hear the rape metaphor applied to plagiarism, it is usually the reader or the author, not the text, who is identified as the rape victim. "When teachers believe they have been given plagiarized work, they feel violated," Dorothy Wells observes, adding that Augustus Kolich's article "captures well the sense that teachers have been insulted and degraded" by plagiarists (Wells 59). Even more commonplace than the assertion that the reader has been raped is the assertion that the author is the victim. Readers can be male or female, but in the binary economy of authorship just described, only a male is an author. Hence the victim of 
plagiarism is the victim of homosexual rape: The male author has been raped by the male plagiarist - a syllogism that, given the premises of contemporary U.S. culture, goes a long way in explaining the fury expressed by many commentators on plagiarism. This metaphor derives its power from the whole set of gendered, sexualized metaphors that construct our emotions about plagiarism. Although one seldom encounters direct assertions of plagiarism as homosexual rape, that enthymeme does inform our culture of authorship, and it can powerfully affect our attitudes not only toward plagiarism and plagiarists but also toward authors whose texts have been plagiarized.

I offer poet Neal Bowers as a case in point. Discovering that another person was publishing Bowers's poems under a variety of pseudonyms, the poet set off in pursuit. He finally ascertained that the culprit was one David Jones, a.k.a. David Sumner. Bowers complained to editors of the literary magazines that published the plagiarized poetry; he confronted Jones; he received very little satisfaction or understanding from anyone; and finally he published a book, Words for the Taking: The Hunt for a Plagiarist, recounting his experiences. James Campbell duly reviewed the book for the Times Literary Supplement. His description of Bowers's feelings sounds like a description of a rape victim: "[S] omething which had been his, uniquely, now felt sullied by filthy hands; the voice, the poet's soul, had been violated." Later in the review, Campbell explicitly invokes the rape metaphor. Bowers's experience of discovering that another person was publishing his poetry was, Campbell says, an experience of "literary rape" (n.p.).

In Words for the Taking, Bowers strives for a milder tone than that which his reviewer, Campbell, would later choose, but he does commit to a remarkable passage:

When I mentioned my predicament to my graduate class . . . a young woman spontaneously offered to find the thief and break his kneecaps. Her suggestion of violence was out of character, but it represented a gender difference I saw in reactions to the basic facts of the case. From the beginning, men were inclined to be philosophical, while women reacted more forcefully, seeming to recognize in the act of plagiarism itself something personal, nearer to home. Perhaps their own vulnerability in a society where women are less safe than men makes them more empathetic. Nancy [Bowers's wife] told me, long before we had any information about David Sumner [the plagiarist], that she intuited he was an ingratiating manipulator, but her specific word for him was "creepy." (Bowers 35)

Like that of his reviewer Campbell, the deep structure of Bowers's understanding of plagiarism seems intertwined with visions of rape and gender hierarchy.

Campbell, however, draws on that association to accomplish a damning dismissal of Bowers and his complaints. Bowers has been raped, Campbell has asserted, and apparently Bowers himself experienced some feelings of that sort. And the rape was by another man; it was the homosexual rape so dreaded in a culture of compul- 
sory heterosexuality. Bowers is the victim of plagiarism; hence he is also the victim of homosexual rape; and hence he has been consigned to the female subject position. And thus Campbell, in a deft turn at the end of his previously noncommittal book review, can adopt attitudes traditionally used to dismiss women who complain of having been raped:

Bowers writes that he is now unable to pick up a pen without wondering if he is simply providing more material for Sumner-Jones. His peculiar fate as the special enthusiasm of a sick shadow elicits the reader's sympathy, but there is a sanctimoniousness about his way of telling his "victim's story" that reacts against that sympathy, as the tale unfolds. (n.p.)

At the most extreme end of the argument-by-metaphor that helps define modern authorship, plagiarism blurs compulsory heterosexuality: The author of the text that is plagiarized as well as readers of the plagiarized texts may feel themselves rape victims or may be assigned by others to that subject position. Plagiarism is what happens when an author, who is by definition both intellectual and male, has physical contact with the contaminated, objectified body (the text of another author) — and the body is by definition nonintellectual and female. Then the male intellect becomes confused by the sensory data of the body and, in a kind of literary hysteria, runs amok, committing crimes of the body: kidnapping, adultery, rape, or gender confusion. Sex and gender, says Judith Butler, are "regulatory fictions that consolidate and naturalize ... power regimes" (33). We can apply the same description to the properties of authorship—originality, proprietorship, and autonomy. These are regulatory fictions that consolidate and naturalize power regimes of gender and sexuality.

The very notion of plagiarism is both product of and reproducer of sexual preference and gender ontology. We must number it among what Butler calls "the categories of identity that contemporary juridical structures engender, naturalize, and immobilize" (5). Authorship in all its forms is attributed to the masculine, and plagiarism threatens that gender by bringing it into proximity to the female. Authorship is not only masculine, but it is also compulsorily autonomous, hence compulsorily heterosexual. Because collaboration is feminine, it is not authorship.

\section{Rejecting Metaphors, Rejecting Plagiarism}

Butler's postfeminism proposes that "a new sort of feminist politics is now desirable to contest the very reifications of gender and identity, one that will take the variable construction of identity as both a methodological and normative prerequisite, if not a political goal" (5). How are we English teachers, having recognized the sexual work of plagiarism, going to deal with it in our classroom representations of textuality? Shall we contest the gendering and sexualizing of plagiarism, and in that contest 
necessarily reify its bifurcations, because we are working against but within its categories? Shall we celebrate that which was previously excoriated? Is the gendering of plagiarism simply a barnacle on the hull of authorship that one might scrape off ? Or does detaching it require some revision of that economy of authorship? Are sexual preference and plagiarism simply incidental associations, or are hierarchical gender and sexuality integral to our fundamental concept of plagiarism-integral to the cultural work accomplished by that concept?

My answer to this last question is "yes." We are accustomed to thinking of plagiarism - and describing it in university regulations-as a purely textual issue. One can examine a text and compare it with an alleged source text to determine whether it is plagiarized. Yet at the same time we think of student plagiarists as people who are either unethical or ignorant of citation conventions. The attribution of ethics (or a lack thereof) personalizes plagiarism, attaching it not to texts but to individuals. The ethical paradigm for interpreting plagiarism associates it with the person, and the gender attached to authorship goes one step further, to associate plagiarism with the physical, hence female, body.

The properties of autonomy, originality, proprietorship, and morality attributed to the modern author do not "merely" describe modern authorship; they also instate and reproduce hierarchized textual values that operate from a model of heterosexual, binary gender. The metaphoric arguments of authorship invest the masculine gender with power and creativity - with subject status - and the feminine with powerlessness and an absence of creativity - with object status. This rhetoric of authorship depicts plagiarism not only as a transgression against textual ethics but also as a transgression against the masculinity that defines binary heterosexuality.

Plagiarism represents authorship run amok-hence gender rendered indeterminate-and thus incites gender hysteria in the community in which it occurs. It receives its power from the subordinated female gender with which it is associated; it is, as Perry's metaphors would have it, a cow. But because it is always impossible to define, always a nuisance to adjudicate, it is a purple cow, always elusive. Stories of its sightings keep us on its trail, but it is not its regulation of textual purity but its implication in hierarchized, heterosexual, binary gender that gives it emotional power.

The metaphors are more than a coincidental add-on; they are the meaning of plagiarism. If we take the metaphors away, plagiarism is bereft of meaning; it becomes a transgressive speech act without consequent injury. Thus, to extract ourselves from the mutual constitution of plagiarism and heterosexual, binary gender, we would have to do more than remove the metaphors; we would have to extract ourselves from the discursive construction of plagiarism itself.

As a significant cultural episteme, that discursive construction is only about a century old; prior to that time, plagiarism was recognized and derided but not invested with any particular cultural significance (see Howard, Standing Ch. 6). Can 
we now engage in an act of metalepsis — can we, in Stuart Moulthrop's words, "jump outside the game" (315)? Can we, once outside that game, do more than analyze it? Can we take action and opt out of our participation in this history? The most fundamental question I am asking is whether we in English Studies are satisfied with the terms of life in this textual culture, or whether we are more inclined toward a revolutionary or at least revisionary response. Changing the textual culture in which the figure of the author excludes women as writers and reproduces compulsory heterosexuality cannot, I believe, be accomplished by revising our metaphors. Those metaphors are not incidental to this textual economy; as Walter Ong observes, "The elements out of which a term"-or in this case, a whole discourse- "is originally built usually, and probably always, linger somehow in subsequent meanings, perhaps obscurely but often powerfully and even irreducibly" (12). Metaphors of gender and sexuality are part of our economy of authorship because our economy of authorship is part of our cultural regulation of gender and sexuality. Gender, weakness, collaboration, disease, adultery, rape, heterosexuality, and property: This whole set of metaphors and associations lies behind every utterance of the word plagiarism, rendering fruitless our pedagogical efforts to teach useful textual strategies and to adjudicate this plagiarism thing.

We might begin a revisionary/revolutionary task by recalling that, in the millennia preceding the fin-de-siècle emergence of plagiarism as a significant player in textual relations, originality was paired with—not pitted against-imitation. While originality was the more valued member of the pair, it was not contrasted with a negative opposite. Instead, imitation, as the other member of the pair, was a respected form of authorship (see Howard, Standing Ch. 4). In the twentieth century, however, plagiarism has replaced imitation in that pair, and the pair has come to function as a hierarchized binary opposition. Meanwhile, imitation, through this association with plagiarism, has become at best a degraded form of authorship-and to some it amounts to plagiarism. If we want to extricate ourselves from gendered, sexualized, hierarchized textual relations, we might begin by reevaluating the scope and value of imitation as a legitimate form of authorship.

This is, however, a mild, very theoretical proposal. Because I am both a theorist and a writing program administrator, I inevitably place these matters in the compelling terms of everyday practice. I ask myself what I am to do, as a WPA, given my beliefs about the roles that our construction of plagiarism play in reproducing and naturalizing social hierarchy and its constituent discourses-including, in this case, the constituent discourse of compulsory heterosexuality and binary gender.

I don't like cheating. I'm mad when I discover that a paper has been ghostwritten. I don't think teachers should look the other way.

But then there are all those other textual activities that wear the name plagiarism: insufficient citation; failure to mark quotations; failure to acknowledge sources; and 
taking brief strings of discourse from a source and patching them, verbatim or slightly altered, into one's own sentences. I have already suggested that the last of these, patchwriting, should be removed from the category of plagiarism (Howard, Standing 159-60). Now I would suggest that everything be removed from that category.

Ancient though the concept of plagiarism is, it is only in the past century that the academy has invested itself emotionally in the topic. For a century we have been trying, to no avail, to define and regulate the category. That we have expressed these efforts in metaphors of gender and sexuality demonstrates that plagiarism is a category through which we attempt to regulate and discipline student bodies. It is not the plagiarized text that we punish, it is the plagiarist - even while we declare that we make our determinations based on the text alone and not on the author's intentions. The whole enterprise smacks too resoundingly of the rhetoric of liberal culture, in which writing is a "product of genius," a "manifestation of one's spiritual nature. Errors in superficial correctness, for example, are considered the result of deep spiritual maladies" (Berlin 31). In the rhetoric of liberal culture, we strive to differentiate the natural elite from the Great Unwashed, all the while pretending (even to ourselves) that everyone has an equal chance at success.

The term plagiarism, denoting a heterogeneous variety of textual activities, is doing cultural work that few of us would deliberately endorse. But notwithstanding attempts (my own included) to redefine that category, as long as the term marks any sort of academic activities, rules, or events, it will continue to do the distasteful, hierarchical work that its metaphors describe, even if some of us eschew or reject those metaphors. Walter Ong is right; the metaphors cannot be detached from the term they construct. Hence the term - and with it the notion of a unity among its heterogeneous subcategories - must be set aside, so that we can deal with those subcategories separately, in terms and under conditions that we ourselves endorse, instead of struggling against the yoke of a liberal cultural legacy.

So my solution is not to expunge the gendered, sexualized metaphors of authorship, as if they were themselves the problem, but to empty out the category that is the problem. Instead of plagiarism, I would choose to speak of fraud, citation, and repetition - three very different categories.

Fraud? Let's go right on getting angry about it. Handing in a paper that somebody else wrote is as bad as falsifying a transcript or hiring a test-taker: It thwarts two of the academy's most basic functions - to teach and to certify intellectual accomplishment. And then let's deal with everything else as issues of pedagogy, not as issues of morality or sexuality. As a WPA, I believe in department- or institution-wide policies that are locally enacted. The teacher might, for example, give an $\mathrm{F}$ for an insufficiently cited paper; a reduced grade for excessive repetition, in which summary masquerades as analysis; and a required revision for patchwriting.

As a disciplinary signifier, plagiarism is unwieldy, unstable, and insidious. Fraud, insufficient citation, and excessive repetition, on the other hand, accomplish the textual 
work of plagiarism without its sexual work. So let's get out of the business of valorizing an elusive originality, criminalizing imitation, and reinforcing prejudices of gender and sexual preference. Let's leave sexual work out of our textual work. Let's quit using the term plagiarism altogether; let's put that purple cow out to pasture.

\section{Notes}

1. Perhaps as a reflex of logical positivism, at one time writers were enjoined to ensure against reproducing more than three consecutive words without providing quotation marks. The 1962 edition of the Harbrace Handbook, for example, offers this advice for avoiding plagiarism: "Usually any conscious quotation (except well-known or proverbial passages) of three or four connected words or more should be placed in quotation marks" (Hodges and Whitten, 5th ed., 409). Perhaps as an adjunct of the increasing popularity of less determinate notions of text, scholars came to scorn such formulae, and by the eighth edition in 1977, the formula had disappeared from the Harbrace plagiarism statement (Hodges and Whitten, 8th ed., 372). Writing in 1986, Alice Drum refers to "one popular formula on how to avoid plagiarism," which is not to repeat "more than three words in a row." She alludes to the formula, however, in a passage that asserts, "Avoiding plagiarism is not simply a matter of following accepted rules ..." (242).

2. The valorization of originality emerged with the eighteenth-century need to justify authors' rights to copy and was further developed in the hierarchical literary theory of Romanticism. For historical background, see Feather, McFarland, Rose, and Sherman. With the twentieth-century emergence of new writing technology, the privileging of originality has seemed less necessary; see, for example, Jaszi and Woodmansee, Randall, and Stillinger.

3. See, for example, Anne Ruggles Gere's account of nineteenth-century women's writing groups as a site of resistance to masculine models of solitary writing and reading, and Linda H. Peterson's account of Margaret Oliphant's disdain for Harriet Martineau's self-portrayal "of a lone woman writer's struggle to publish her work and achieve fame" (148).

4. For genealogies and explications of the role of originality in modern authorship, see Randall and Meltzer. For an example of the valorization of originality in twentieth-century literary theory, see Eliot. And for an example of its valorization in foundational composition theory, see Emig.

5. Aristotle's Politics (especially in Book I but also in Book V) provides one of the many influential ancient sources in which soul (rationality) was attributed primarily to men and body (emotionality) to women; hence it made sense for the rational man to rule over the irrational woman. The tradition has continued to the present, to the extent that geographer Nancy Duncan must observe,

The reason why women tend to be among the excluded and why women who have managed to be admitted to active participation in the public sphere have usually done so according to implicitly male rules, has to do with the mind/body dualism. This dualism and its spatial counterpart- the public/private division — can be shown to be an important structuring principle upon which characteristics commonly associated with masculinity and femininity are arrayed. (3)

Writing in the same volume, Linda Alcoff explains that in our culture even today reason is a male attribute; it "has been defined in opposition to the feminine, such that it requires the exclusion, transcendence and even the domination of the feminine, of women and of women's traditional concerns, which have been characterized as the site of the irreducibly irrational particular and corporeal" (14).

\section{WORKS CITED}

Alcoff, Linda Martín. "Feminist Theory and Social Science: New Knowledges, New Epistemologies." Bodyspace: Destabilizing Geographies of Gender and Sexuality. Ed. Nancy Duncan. New York: Routledge, 1996. 13-27.

Aristotle. The Politics of Aristotle. Ed. and Trans. Ernest Barker. New York: Oxford UP, 1946, 1958. 
Berlin, James. Rhetorics, Poetics, and Cultures: Refiguring College English Studies. Urbana: NCTE, 1996.

Bloom, Harold. The Anxiety of Influence: A Theory of Poetry. New York: Oxford UP, 1973.

Bowers, Neal. Words for the Taking: The Hunt for a Plagiarist. New York: Norton, 1997.

Brody, Miriam. Manly Writing: Gender, Rhetoric, and the Rise of Composition. Carbondale: Southern Illinois UP, 1993.

Buranen, Lise, and Alice M. Roy, eds. Perspectives on Plagiarism and Intellectual Property in a Postmodern World. Albany: SUNY P, 1999.

Butler, Judith. Gender Trouble: Feminism and the Subversion of Identity. New York: Routledge, 1990.

Campbell, James. "The Sincerest Form?” Times Literary Supplement 28 Feb. 1997. 31 March 1997. $<$ http://www.the-tls.co.uk:80/tp/3040264/>.

Cornell University, Office of the Dean of the Faculty. "The Code of Academic Integrity and Acknowledging the Work of Others." August 1997.

Drum, Alice. "Responding to Plagiarism." College Composition and Communication 37 (May 1986): 241-43.

Duncan, Nancy. "(Re)placings." Bodyspace: Destabilizing Geographies of Gender and Sexuality. Ed. Nancy Duncan. New York: Routledge, 1996. 1-12.

Eliot, T. S. "Tradition and the Individual Talent." The Sacred Wood. London: Methuen, 1960. Rpt. in Authorship: From Plato to the Postmodern. Ed. Séan Burke. Edinburgh: Edinburgh UP, 1995. 73-80.

Emig, Janet. "Writing as a Mode of Learning." College Composition and Communication 28.2 (May 1977): 122-28. Rpt. in Cross-Talk in Comp Theory: A Reader. Ed. Victor Villanueva, Jr. Urbana: NCTE, 1997. 7-15.

Feather, John. "From Rights in Copies to Copyright: The Recognition of Authors' Rights in English Law and Practice in the Sixteenth and Seventeenth Centuries." The Construction of Authorship: Textual Appropriation in Law and Literature. Ed. Martha Woodmansee and Peter Jaszi. Durham: Duke UP, 1994. 191-210.

Geosits, Margaret S., and William R. Kirk. "Sowing the Seeds of Plagiarism.” Principal 62.5 (May 1983): $35-38$.

Gere, Anne Ruggles. Intimate Practices: Literacy and Cultural Work in U.S. Women's Clubs, 1880-1920. U of Illinois P, 1997.

Gilbert, Sandra M., and Susan Gubar. "Infection in the Sentence: The Woman Writer and the Anxiety of Authorship." The Madwoman in the Attic: The Woman Writer and the Nineteenth-Century Literary Imagination. New Haven: Yale UP, 1979. Rpt. in Feminisms: An Anthology of Literary Theory and Criticism. Ed. Robyn R. Warhol and Diane Price Herndl. New Brunswick: Rutgers UP, 1991. 289-300.

Hodges, John C., with Mary E. Whitten. Harbrace College Handbook. 5th ed. New York: Harcourt, 1962.

Hodges, John C., and Mary E. Whitten. Harbrace College Handbook. 8th ed. New York: Harcourt, 1977.

Hodges, John C., Winifred Bryan Horner, Suzanne Strobeck Webb, and Robert Keith Miller. Harbrace College Handbook. Rev. 13th ed. Fort Worth: Harcourt, 1998.

Howard, Rebecca Moore. "The Ethics of Plagiarism.” The Ethics of Writing Instruction: Issues in Theory and Practice. Ed. Michael A. Pemberton. Norwood: Ablex. Forthcoming.

. "The New Abolitionism Comes to Plagiarism." Perspectives on Plagiarism and Intellectual Property in a Postmodern World. Ed. Lise Buranen and Alice M. Roy. Albany: SUNY P, 1999. 87-98.

“A Plagiarism Pentimento.” Fournal of Teaching Writing 11 (Summer 1993): 233-46.

"Plagiarisms, Authorships, and the Academic Death Penalty." College English 57 (November 1995): 708-36.

- Standing in the Shadow of Giants: Plagiarists, Authors, Collaborators. Norwood: Ablex, 1999.

Irigaray, Luce. This Sex Which Is Not One. Trans. Catherine Porter with Carolyn Burke. Ithaca: Cornell UP, 1985. 
Jaszi, Peter, and Martha Woodmansee. "The Ethical Reaches of Authorship.” South Atlantic Quarterly 95 (Fall 1996): 947-77.

Kolich, Augustus M. "Plagiarism: The Worm of Reason.” College English 45 (February 1983): 141-48.

Lewis, David Levering. "Failing to Know Martin Luther King, Jr." Journal of American History 78 (June 1991): 81-85.

Lunsford, Andrea A., and Lisa Ede. Singular Texts/Plural Authors: Perspectives on Collaborative Writing. Carbondale: Southern Illinois UP, 1990.

Malloch, A. E. “A Dialogue on Plagiarism.” College English 38 (1976): 165-74.

Mallon, Thomas. Stolen Words: Forays into the Origins and Ravages of Plagiarism. New York: Ticknor, 1989.

McFarland, Thomas. Originality and Imagination. Baltimore: Johns Hopkins UP, 1985.

Meltzer, Françoise. Hot Property: The Stakes and Claims of Literary Originality. Chicago: U Chicago P, 1994.

Miller, Keith D. Voice of Deliverance: The Language of Martin Luther King, 7r. and Its Sources. 1992. Athens: U Georgia P, 1998.

Mooney, Carolyn J. "Critics Question Higher Education's Commitment and Effectiveness in Dealing with Plagiarism." Chronicle of Higher Education 12 Feb. 1992: A13, A16.

Moulthrop, Stuart. "Rhizome and Resistance: Hypertext and the Dreams of a New Culture." Hyper/Text/Theory. Ed. George P. Landow. Baltimore: Johns Hopkins UP, 1994. 299-319.

Nienhuis, Terry. “Curing Plagiarism with a Note-Taking Exercise.” College Teaching 37.3 (Summer 1989): 100.

Ong, Walter J. Orality and Literacy: The Technologizing of the Word. London: Methuen, 1982.

Pappas, Theodore. "Truth or Consequences: Redefining Plagiarism.” Cbronicles (September 1993): 41-42.

Perry, William G., Jr. "Examsmanship and the Liberal Arts." Examining in Harvard College: A Collection of Essays by Members of the Harvard Faculty. Cambridge: Harvard UP, 1963.

Peterson, Linda H. Traditions of Victorian Women's Autobiography: The Poetics and Politics of Life Writing. Charlottesville: UP of Virginia, 1999.

"Plagiarism in the Classroom: Readers Explain How They Define It and How They Deal with It." Council Chronicle 3.5 (June 1994): 14-15.

"Plagiarism Is Rampant, a Survey Finds." New York Times 1 Apr. 1990. 36-37.

Randall, Marilyn. "Appropriate(d) Discourse: Plagiarism and Decolonization.” New Literary History 22 (1991): 525-41.

Rankin, Elizabeth. Seeing Yourself as a Teacher: Conversations with Five New Teachers in a University Writing Program. Urbana: NCTE, 1994.

Rose, Mark. Authors and Owners: The Invention of Copyright. Cambridge: Harvard UP, 1993.

Sherman, Brad, and Alain Strowell, eds. Of Authors and Origins: Essays on Copyright Law. New York: Oxford UP, 1994.

Spellmeyer, Kurt. "On Conventions and Collaboration: The Open Road and the Iron Cage." Writing Theory and Critical Theory. Ed. John Clifford and John Schilb. New York: MLA, 1994. 73-95.

Stallybrass, Peter, and Allon White. The Politics and Poetics of Transgression. Ithaca: Cornell UP, 1986.

Stewart, Susan. Crimes of Writing: Problems in the Containment of Representation. New York: Oxford UP, 1991.

Stillinger, Jack. Multiple Authorship and the Myth of Solitary Genius. New York: Oxford UP, 1991.

Wall, Wendy. The Imprint of Gender: Authorship and Publication in the English Renaissance. Ithaca: Cornell UP, 1993.

Wells, Dorothy. "Causes of Unintentional Plagiarism." Writing Program Administration 16.3 (Spring 1993): 59-71.

“We Want to Know: How Do You Define Plagiarism?” Council Chronicle 3.2 (November 1993): 8.

"What Do You Do About Plagiarism? Readers Continue to Respond." Council Chronicle 4.1 (September 1994): 14-15. 